REVISTA de

PEDAGOGIE

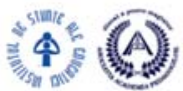

JOURNAL of

PEDAGOGY

http://revped.ise.ro

Print ISSN 0034-8678; Online ISSN: 2559 - 639X

\title{
DISCOURSES IN COMPETITION ON THE TEACHER'S \\ ROLE IN HIGH SCHOOL
}

DISCURSURI COMPETITIVE DESPRE ROLUL PROFESORULUI, ÎNTR-UN LICEU TEORETIC

\section{Octavia Mihaela BORȘ}

\author{
Journal of Pedagogy, 2018 (1), 135 - 157 \\ https://doi.org/10.26755/RevPed/2018.1/135
}

The online version of this article can be found at: http://revped.ise.ro/category/2018-en/

\section{(1) (1)(2)}

This work is licensed under the Creative Commons Attribution-NonCommercial-ShareAlike 4.0 International License.

To view a copy of this license, visit http://creativecommons.org/licenses/by-nc-sa/4.0/ or send a letter to Creative Commons, PO Box 1866, Mountain View, CA 94042, USA.

Published by:

\section{INSTITUTUL DE ȘTIINȚE ALE EDUCAȚIEI}

http://www.ise.ro/

Further information about Revista de Pedagogie - Journal of Pedagogy can be found at:

Editorial Policy: http://revped.ise.ro/editorial-policy/

Author Guidelines: http://revped.ise.ro/the-writer-guide-2/ 


\title{
DISCURSURI COMPETITIVE DESPRE ROLUL PROFESORULUI, ÎNTR-UN LICEU TEORETIC
}

\author{
Octavia Mihaela Borş* \\ Institutul de Ştiin e ale Educa iei \\ Bucureşti / România \\ octavia.bors@ise.ro
}

\section{Rezumat}

Acest articol descrie discursurile competitive despre rolul profesorului la clasă, identificate într-un colegiu teoretic din mediul urban mic, pe baza analizei a 11 interviuri semi-structurate cu profesori de liceu. Interpretarea modului în care profesorii invocă rolul profesorului în poveştile lor identitare, a dezvăluit următoarele discursuri competitive: profesorul trebuie să transmită cunoştin e versus profesorul trebuie să înlesnească în elegerea; profesorul trebuie să noteze „obiectiv” versus profesorul trebuie să noteze ,flexibil”. Argumentul principal al articolului este că în liceul studiat, domină ideea că profesorul trebuie să transmită cunoştin e şi să noteze ,flexibil”. A nota „flexibil" înseamnă a răspunde aşteptărilor părin ilor, directorului şi colegilor de „,a da note mari” anumitor elevi şi/sau tuturor elevilor. Această aşteptare din partea profesorilor este favorizată de politica universită ilor de a include media generală din anii de liceu, în criteriile de admitere la programele de licen ă, dar şi de politica liceului de a da posibilitatea părin ilor să aleagă profesorii copiilor lor pe baza unei cereri şi dacă există consens între părin i.

Cuvinte-cheie: analiză de discurs, colegiu teoretic, evaluare a elevilor, politici de admitere, programă.

\section{Abstract}

The article describes the competitive discourses on the role of teachers, identified in a high school, in Romania, based on an analysis of 11 individual interviews

* Cercetător ştiin ific drd., Institutul de Ştiin e ale Educa iei, Bucureşti, România. 
with teachers. The references to the role of teachers, in the teachers'identifying stories, revealed the following competitive discourses: a teacher should transmit knowledge versus a teacher should enhance the students ' understanding; a teacher should grade 'objectively' versus a teacher should grade 'flexible'. Moreover, the analysis shows that, in the studied high school, the dominant discourse assigns to teachers, the role to transmit knowledge and to grade 'flexible'. To grade 'flexible " means to accommodate the parents', principals' and colleagues 'expectations to give good grades to some students or all students, in general. This discourse is privileged in the studied field by the fact that while most universities in Romania used to admit students based on the average grade of high school years, informally, the high school gives students and parents the possibility to choose their teachers only based on formal asking and class consensus.

Keywords: curriculum, discourse analysis, grading students, theoretical high school, university admission.

\section{Introducere}

Cercetarea îşi propune să răspundă la întrebarea care sunt discursurile competitive, într-un liceu teoretic studiat, privind rolul profesorului?, conceptul de discurs fiind folosit în în elegerea lui Foucault. În acest sens, s-a investigat ce idei posibile despre rolul profesorului formulează 11 profesori, în poveştile lor identitare, pe care le aşază în opozi ie şi care sunt ideile în raport cu care se auto-evaluează. Analiza datelor colectate calitativ (interviuri individuale) au dezvăluit două teme centrale în poveştile identitare ale profesorilor: utilizarea programei şi evaluarea elevilor. Modul în care profesorii se prezintă în raport cu aceste teme au permis identificarea discursurilor competitive din liceu şi problematizarea lor în termeni de dominan ă. Mai departe, pe baza explica iilor primite de la profesori, au fost identificate practicile şi politicile institu ionale care favorizează aceste discursuri.

În continuare, pentru prezentarea analizei şi a rezultatelor, sunt redate poveştile identitare a două cazuri ilustrative (Mihai şi Diana) şi o descriere a cum se pozi ionează profesorii pe cele două teme centrale: folosirea programei şi evaluarea elevilor. Cercetarea realizată este exploratorie, nu oferă rezultate ce pot fi generalizate la nivel na ional, dar invită cititorii la reflec ie şi derularea unor investiga ii care să testeze şi/sau să completeze concluziile. 
Liceul studiat are statut de „,colegiu na ional”, profil teoretic, aproximativ 1.500 de elevi, 80 de cadre didactice şi patru specializări: filologie, matematicăinformatică, biologie-chimie şi ştiin e sociale. Liceul este situat într-un oraş de 20.000 de locuitori, unde există alte două licee, ambele cu profil tehnologic. În 2015, unitatea şcolară a avut cele mai mari medii de admitere din localitate $(8,20$ la profilul filologic, 8,90 la profilul matematică-informatică, 9,10 la profilul biologie-chimie), rata de absolvire de $95 \%$ şi rata de promovabilitate la examenul de bacalaureat de $96 \%$ (peste media na ională de $71 \%$ ). Toate cadrele didactice sunt calificate, iar dintre acestea 93\% sunt titulare, majoritatea are gradul didactic I şi 10 profesori au titlul de doctor. Unitatea şcolară are un director principal şi doi directori adjunc i.

\subsection{Cadru de analiză: poveşti identitare, discursuri competitive}

Discursurile competitive despre rolul profesorilor din liceul studiat au fost formulate pe baza analizei poveştile identitare ale profesorilor, mai ales a modului în care aceştia se pozi ionează în rela ie cu evaluarea elevilor şi folosirea programei. Conceptul de identitate este larg folosit, acesta se întâlneşte în discipline precum psihologie, sociologie sau antropologie. Fiecărei discipline şi şcolilor aferente de gândire le corespund diferite defini ii ale conceptului. Sinteza realizată de Beauchamp şi Thomas (2009) cu privire la temele şi modul în care identitatea profesorilor este studiată în literatura ştiin ifică actuală, dezvăluie existen a unor suprapuneri între diferite perspective, dar şi întrebări despre identitate, la care cercetarea trebuie să răspundă. În prezentul studiu, se recunoaşte existen a diferitelor perspective de cercetare a identită ii şi a efortului de a crea legături între acestea, dar conceptul este folosit într-un sens restrâns, în în elegerea dată de Sfard şi Prusak (2005).

În prezenta analiză, cuvântul identitate este folosit cu sensul de ,poveşti despre oameni" (Sfard, \& Prusak, 2005, p. 14), cu alte cuvinte, identitatea este o expunere, o înlăn uire de afirma ii prin care o persoană se prezintă, incluzând ceea ce are sens pentru ea însăşi, despre ea însăşi, într-un anumit context. În prezenta cercetare, identitate şi poveste identitară sunt folosi i interşanjabil. 
Sfard şi Prusak propun această defini ie ca o alternativă la în elegerea identită ii ca ,un anumit tip de persoană” (2005, p. 16) şi un răspuns la preocuparea anumitor cercetători de a depăşi viziunea esen ialistă asupra identită ii. Folosind conceptul în în elegerea lui Sfard şi Prusak (2005), misiunea rămasă cercetătorului nu este să identifice adevărul despre felul de a fi al unei persoane sau să evalueze în ce măsură identitatea responden ilor se apropie de repere normative (de exemplu, competen ele profesionale ale profesorului din România), ci să descrie povestea pe care o persoană o spune despre sine, într-un anumit timp şi spa iu.

În termeni opera ionali, Sfard şi Prusak sus in că identitatea reprezintă ,o colec ie de poveşti despre oameni” (p. 16) dacă aceste ,nara iuni ${ }^{1}$ sunt concrete, fidele şi semnificative" (Sfard şi Prusak, 2005, p. 16). Conform autorilor, o poveste este concretă dacă povestitorul descrie cine este de obicei, în mod repetat, niciodată mai degrabă decât ce face; este fidelă dacă, întrebat, povestitorul ar confirma că povestea este o reprezentare corectă a realită ii şi o poveste este semnificativă, dacă povestitorul ar fi bulversat de schimbarea acesteia.

Sfard şi Prusak (2005) sus in că în fiecare poveste identitară există persoana identificată (A), autorul poveştii (B) şi C (destinatarul poveştii) şi poate fi reprezentată prin ${ }_{B} A_{C}$; bineîn eles, aceste roluri se pot suprapune. Conform acestei reprezentări, poveştile spuse în cadrul interviurilor prezentei cercetări sunt de tipul ${ }_{\mathrm{A}} \mathrm{A}_{\mathrm{C}}$, profesorul povesteşte despre sine, deci este atât persoana identificată, cât şi autorul poveştii, iar cercetătorul este destinatarul. Continuând în această logică, pentru că articolul nu reproduce complet interviurile cu profesorii, ci prezintă interpretări şi selec ii, acestea trebuie privite ca ,poveşti despre poveşti” (Sfard \& Prusak, 2005, p. 20), de tipul: Cercetător ${ }_{\text {Profesor }}$ Profesor ${ }_{\text {Cercetător }}{ }_{\text {Cititor }}$.

În prezenta cercetare, răspunsurile profesorilor la situa ia de interviu vor fi tratate ca poveşti identitare; acestea nu ne indică ce fel de profesori sunt în liceu sau cum se comportă ei la clasă, ci cum aleg să se prezinte. Imaginile pe care profesorii le-au creat în fa a cercetătorului vor fi analizate pentru a identifica discursurile competitive despre rolul profesorului din liceul studiat.

Ideea de discurs apare şi la Sfard şi Prusak (2005, p. 15) care definesc 
identitatea ca practică discursivă, altfel spus, o poveste identitară nu există decât prin prima semnifica iei pe care povestitorul o dă limbajului său. Sfard şi Prusak (2005), asemeni altor lingvşti sau socio-lingvişti (Cohen, 2008; Alsup, 2008) folosesc conceptul de discurs pentru a descrie modul în care indivizii folosesc limbajul, având asump ia că sensul cuvintelor este construit şi trebuie interpretat în context.

În prezenta analiză, conceptul de discurs este folosit în în elegerea lui Foucault, o perspectivă care nu o exclude pe cea a autorilor Sfard şi Prusak (2005), dar care adaugă o dimensiune socială: discursul (limbajul) nu mai este privit doar în rela ie cu individul, ci şi cu realitatea pe care o descrie (în cazul acestei cercetări: rolul profesorului). Astfel, prin discurs, se va în elege limbajul asociat unui obiect - ce este spus, cine spune, unde şi când este spus despre obiect (Foucault, 1998). Ball (2013, în Mills, 2005) subliniază că, în în elegerea lui Foucault, discursul este limbaj, dar nu trebuie ,echivalat” cu limbajul.

În rândul lingviştilor, limbajul este pus în rela ie cu individul, iar în perspectiva lui Foucault, limbajul este pus în rela ie cu un obiect, într-un anumit timp şi spa iu. Alsup (2008), comparând conceptul discurs în în elegerea lui Foucault şi a socio-lingvistului Gee, sus ine că Gee foloseşte conceptul pentru a descrie limbajul folosit de individ, pentru a da sens identită ii, ac iunilor şi obiectelor, iar pentru Foucault, discursul descrie ideile care s-au împământenit într-un anumit timp şi spa iu, ceea ce este acceptat sau privilegiat din tot ceea ce poate fi spus despre o anumită realitate.

Conform lui Foucault (1998), într-un câmp social, ideile se află într-o permanentă competi ie. Discursurile competitive sunt ideile contradictorii despre o anumită realitate, care co-există într-un câmp, la un moment dat. Ideile (limbajul) care, la un moment dat, deşi selective, se impun ca definitorii pentru o anumită realitate, reprezintă discursul dominant (Spratt, 2017). Acesta intră în rela ie cu discursuri contradictorii, are o genealogie, se formează şi dispare în anumite contexte sociale, politice, economice (Foucault, 1998; Gibbs, 2015).

Care este locul individului în această competi ie pentru idei (limbaj)? Ideilor şi limbajului aferent despre realitate, îi corespund reprezentări specifice despre 
ceea ce pot fi oamenii. Astfel, un discurs dominant generează ceea ce Foucault (1998) numeşte pozi ii sau în termeni de limbaj, categorii în raport cu care indivizii sunt evalua i şi se auto-evaluează. Prin categoriile pe care le generează, discursurile dominante includ şi exclud, pot fi eliberatoare sau opresive în raport cu individul (Foucault, 1998). Foucault (Gibbs, 2015) sus ine că discursurile trebuie privite în rela ie cu raporturile de putere; limbajul folosit pentru a descrie realitatea reprezintă sursa şi miza puterii; astfel, limbajul (ideile) în uz reprezintă o oglindire a raporturilor de putere, dezvăluie unde este concentrată puterea şi poate fi investigat în acest sens. Foucault (1998) şi Ball (2013) arată că, mai ales practicile institu ionale (care reglementează via a socială), inclusiv în educa ie, prin discursurile pe care le incumbă, favorizează anumite pozi ii (categorii, idei despre oameni dominante sau nu).

În poveştile lor identitare, vorbind despre sine, profesorii formulează idei despre ce înseamnă să fii profesor, pe unele dintre ele le aşază în contradic ie. Opozi iile cu care operează profesorii în poveştile identitare, vor fi valorificate pentru identificarea discursurilor competitive din liceul studiat. Discursurile identificate vor fi problematizate în termeni de discurs dominant în func ie de ideile despre rolul profesorilor în raport cu care profesorii se auto-evaluează şi formulează aprecieri de conformitate sau non-conformitate, în poveştile lor identitare.

\section{Metodologie}

Datele incluse în analiză au fost colectate în mai-iunie 2016, în cadrul proiectului de dizerta ie al autoarei. Cercetarea a inclus profesori care predau sau au predat la liceul ales pentru realizarea studiului de caz. Într-o primă etapă a cercetării, s-a urmărit colectarea unor date relevante pentru a descrie discursul profesorilor care se auto-identifică ca moderni în predare. Însă, pe parcursul colectării datelor, responden ii au adus în discu ie, în mod repetat, noi teme (ex.: utilizarea programei, evaluarea elevilor), ceea ce a determinat extinderea aspectelor cercetate şi creşterea eşantionului investigat. Acest lucru a permis valorificarea datelor pentru a identifica discursurile competitive despre rolul profesorului, în liceul studiat. 
Datele au fost colectate folosind interviuri semi-structurate, ce au inclus întrebări de deschidere prestabilite şi întrebări formulate pe parcursul intervievării profesorilor, urmărind clarificarea răspunsurilor primite. Întrebările de deschidere (prestabilite) au fost formulate larg (de exemplu, Ce înseamnă pentru dvs. să fi i profesor?), astfel încât să permită respondentului să abordeze sub-temele din unghiul pe care îl consideră semnificativ. Grila semi-structurată de interviu, elaborată în faza de proiectare a cercetării, a inclus următoarele sub-teme: traseul profesional al respondentului (studii, momente semnificative, alegerea carierei didactice, venirea şi/sau plecarea din liceul studiat), rolul de profesor (semnifica ie, status, drepturi, îndatoriri, cod de conduită), preferin e de predare, schimbări resim ite în câmpul educa ional, opiniile colegilor despre schimbările raportate. Odată cu extinderea interesului de cercetare, în interviuri au fost incluse două noi sub-teme: utilizarea programei şi evaluarea elevilor. Ordinea abordării sub-temelor a urmărit firul narativ al respondentului.

În culegerea datelor s-a optat pentru o strategie de eşantionare continuă. În func ie de accesibilitate şi nevoile de în elegere în profunzime a temelor, au fost incluşi noi responden i (Creswell, 2007; Stănciulescu, 2015). Studiul a inclus 11 cazuri, investiga ia a fost oprită în momentul în care s-a ajuns la satura ie empirică.

În faza de proiectare a cercetării, în urma interviurilor pilot, s-a făcut o selec ie ini ială a subiec ilor pe baza accesibilită ii, intindu-se includerea a 6-8 cazuri ilustrative pentru scopul cercetării (cazuri intense): profesori hetero-identifica i ca având o abordare pedagogică modernă şi al ii ca având una tradi ională. De asemenea, în selec ia cazurilor s-a urmărit ob inerea unui maximum de varia ie în raport cu următoarele criterii: disciplina predată (discipline socio-umane, respectiv reale; discipline de examen sau nu), statutul didactic al profesorului (titular, respectiv suplinitor), nivel de calificare (debutant, gradul II, gradul I) şi dacă ocupă sau nu func ii administrative. S-a urmărit ob inerea acestui maximum de varia iei pentru a controla dacă se asociază cu diferen e în discursul profesorilor. Datele nu au arătat pattern-uri în acest sens. Odată cu extinderea interesului de cercetare, au fost introduse noi cazuri: profesori despre care responden ii anteriori au spus că au o perspectivă diferită despre rolul profesorului, utilizarea programei şi/sau evaluarea elevilor. 
Datele incluse în analiză provin din 11 interviuri semi-structurate ${ }^{2}$ :

- Ioana - profesoară de limba engleză, disciplină socio-umană, de examen, titular, gradul I, 13 ani vechime, studii superioare (masterat), fără func ii administrative;

- Dana - profesoară de istorie, educa ie civică şi limba franceză, discipline socio-umane, de examen, suplinitor, debutant, studii superioare (masterat), fără func ii administrative, predă şi la o şcoală din mediul rural, nu este cunoscută vechimea;

- Diana - profesoară de limba engleză, disciplină socio-umană, de examen, titular, debutant, studii superioare (masterat), fără func ii administrative, a predat 1 an în unitatea şcolară studiată, 4 ani vechime;

- Irina - profesoară de religie, disciplină socio-umană, nu este de examen, titular, gradul I, studii superioare (masterat), func ie de consilier educativ, nu este cunoscută vechimea;

- Maria - profesoară de psihologie, disciplină socio-umană, de examen, titular, gradul I, studii superioare (masterat nefinalizat), rolul de consilier şcolar, nu este cunoscută vechimea;

- Sorana - profesoară de economie şi filosofie, disciplină socio-umană, nu este de examen, titular, gradul I, 30 de ani vechime, studii superioare (masterat), şeful comisiei de dirigin i, membru în consiliul administrativ;

- Anca - profesoară de limba şi literatura română, disciplină socio-umană, de examen, titular, gradul I, studii superioare (masterat), a fost director adjunct, nu este cunoscută vechimea;

- Mihai - profesor de fizică, disciplină reală, de examen, titular, gradul I, 18 ani vechime, studii superioare (masterat), fără func ie administrativă;

- Corina - profesoară de istorie, disciplină socio-umană, de examen, titular, gradul I, studii superioare (doctorat), metodist, nu este cunoscută vechimea;

- Elena - profesoară de informatică, disciplină reală, de examen, titular, gradul I, studii superioare (masterat), fără func ie administrativă, nu este cunoscută vechimea;

- Ilinca - profesoară de limba şi literatura română, disciplină socio-umană, de examen, titular, gradul I, studii superioare (masterat), fost director adjunct, nu este cunoscută vechimea. 


\section{Poveşti identitare}

În poveştile lor identitare, profesorii au alternat între a se descrie pe sine, a se aşeza în opozi ie cu al i profesori, a se delimita de anumite practici din liceu, a-şi exprima acordul sau dezacordul pe diferite teme şi a descrie idealuri de conduită pentru un cadru didactic. Fiecare poveste identitară a profesorilor este o combina ie unică de reprezentări şi semnifica ii, însă con ine idei despre rolul profesorului, puse în opozi ie; aceste idei indică discursurile competitive din câmp. Logic, reprezentările aşezate în opozi ie nu se exclud reciproc, dar, în poveştile lor, profesorii le dau semnifica ii opuse, ceea ce permite interpretarea lor în termeni de discurs.

Mihai (profesor de fizică), Irina (profesoară de religie), Maria (profesoară de psihologie) şi Ioana (profesoară de engleză), Sorana (profesoară de economie şi filosofie), Dana (profesoară de istorie şi educa ie civică) şi Ilinca (profesoară de limba şi literatura română) se prezintă ca profesorul care se adaptează în func ie de evolu ia elevilor, ei fac tot ceea ce fac pentru ca elevii să în eleagă. Diana (profesoară de istorie), Anca (profesoară de limba şi literatura română), Elena (profesoară de informatică) şi Corina (profesoară de istorie) se identifică mai degrabă cu profesorul care transmite cunoştin e elevilor, ele fac tot ceea ce fac pentru a ,termina programa”. Aceste diferen e de discurs devin vizibile mai ales când profesorii aduc în discu ie programa, această observa ie va fi tratată extins în una dintre următoarele sec iuni ale articolului.

Mihai (profesor de fizică) şi Ioana (profesoară de engleză) se prezintă ca profesori „obiectivi” în evaluare. Diana (profesoară de istorie) şi Corina (profesoară de istorie) povestesc că s-au adaptat şi în prezent dau ,note mari”. Sorana (profesoară de economie şi filosofie), Irina (profesoară de religie), Maria (profesoară de psihologie), Anca (profesoară de limba şi literatura română) şi Ilinca (profesoară de limba şi literatura română) nu se pozi ionează explicit pe această temă, dar povestesc despre ,a da note mari” sau „mai mari” ca despre un fapt, o realitate acceptată. Una dintre următoarele sec iuni ale articolului tratează, în detaliu, cum se prezintă profesorii în raport cu această temă.

În continuare sunt redate poveştile identitare ale Dianei şi ale lui Mihai. Nara iunile reconstituite aici nu descriu cine sunt Diana şi Mihai sau felul în 
care se comportă la clasă, ci modul în care cei doi se imaginează pe sine, în rolul de profesor.

\subsection{Mihai, profesor de fizică}

„Rolul profesorului este de a forma oameni, nu ştiu, de a forma oameni, părerea mea. [...] Stilul de predare, mă rog... Ştiu care sunt, să spunem aşa, punctele dificile în predarea unei lec ii, am fost şi eu elev, şi insist pe acele lucruri cu explica ii până când simt eu că elevul în elege. [...] $\mathrm{Nu}$, elevul este şi el un om, trebuie respectat, trebuie în eles, dar notarea trebuie să fie obiectivă, adică elevului trebuie să îi ară $i$ acolo unde este. Dacă el este de 7, trebuie să îi dai 7, dacă el este de 5, trebuie pus 5, în aşa fel încât elevul să ştie unde se află şi ce mai are de pus să ajungă acolo unde sperăm noi că vrea să ajungă."

Mihai predă fizică din 1998. A venit în liceu în 2001-2002, „pe vremea domnului Lazăr [pseudonim] ”. Acum are gradul I şi este membru în consiliul de administra ie. De-a lungul timpului, a refuzat să devină metodist şi men ionează acest aspect delimitându-se de mersul lucrurilor în sistem: „Dacă mă mai pune i metodist, nu o să mai ieie mul i gradul.". Mihai se prezintă ca „obiectiv în evaluare”.

Întrebat cum a luat decizia de a deveni profesor, Mihai povesteşte mult despre profesorii săi din gimnaziu, liceu şi universitate. În gimnaziu, Mihai a „,̂ndrăgit” matematica; ajuns la liceu, şi-a pierdut entuziasmul pentru matematică ,din cauza, mă rog, profesorului”, dar 1-a descoperit pe „,domnul profesor Georgescu [pseudonim]” care i-a „însuflat dragostea fa $\breve{a}$ de obiectul ăsta, fizică”.

Pentru Mihai, a fi profesor înseamnă să î i cunoşti foarte bine disciplina, să explici, să te adaptezi în func ie de cât au în eles elevii, să respec i elevul şi părin ii, să fii în dialog cu ei şi dirigintele, să fii ferm în anumite situa ii, să fii obiectiv în notare şi chiar dacă „nu to i sunt de fizică”, să găseşti timp pentru fiecare elev. 
Mihai se prezintă în opozi ie fa ă de profesorii care folosesc notele pentru a „,buşi” elevii: „nu îmi place să «semăn teroare», să spunem aşa, nu, deci, discutăm cu elevul, învă ăm elevul cum să lucreze, cum să procedeze, cum să se descurce, ce trebuie să facă când iese la tablă”. Legat de aceeaşi temă, Mihai povesteşte despre o schimbare, fa ă de începuturile carierei sale, acum evaluează elevul de mai multe ori înainte de a-1 nota şi pentru aceleaşi cunoştin e predate, oferă o notă mai mare cu un punct. Mihai atribuie această schimbare unei evolu ii profesionale naturale. Mihai respinge ideea că deciziile lui privind notarea sunt influen ate de părin i: „Presiunea părin ilor nu o simt absolut deloc şi nu am sim it-o niciodată.[...] Nu mi s-a întâmplat niciodată, dar dacă aş fi pus în situa ia, eu ştiu, o clasă să nu mă accepte, pentru că, ştiu eu, se poate întâmpla aşa ceva, nu ştiu din ce cauză, că nu î $i$ place...nu place de figura ta, nicio problemă, mă dau deoparte.".

Satisfac ia lui Mihai sunt dovezile că elevii aplică ceea ce au învă at: „Să vezi că, mă rog, o parte dintre elevii cu care lucrezi prind via ă la obiectul fizică, se descurcă, aplică rezolvări de probleme, rezultatele la olimpiadele de fizică care, mă rog, văd că, în ultima vreme, [...] seamănă din ce în ce mai mult cu SF-urile.”.

\subsection{Diana, profesoară de engleză}

„[Când erai mică cum percepeai profesia de profesor?] O percepeam ca o împărtăşire de cunoştin e şi acum am ce împărtăşi, dar nu am cui [...] Da, mi-au dinamitat tot sistemul de valori, pe care îl aveam şi cu care am crescut. Adică, eu am crescut cu o gândire din aia, pură [...] Şcoala, o vedeam ca pe ceva sacru. [...] Să ai ocazia să citeşti cât mai mult, să te documentezi, să, wow, o vedeam aşa ca pe ceva măre ... şi când am ajuns şi am venit la catedră şi am văzut că oamenii, de fapt, nici măcar nu se apropie de ce îmi imaginam eu, nici măcar nu se apropie de ceea ce în elegeam eu. Şcoala, o în elegeam, ştii, ca pe Şcoala lui Socrate, aşa ştii, unde se adunau în jurul unui profesor şi în elegeau lumea în general, [...]. Deci impactul a fost mare şi totul s-a distrus, a rămas doar aşa, o amintire...” 
Diana predă limba engleză din 2010, la liceul studiat a fost profesoară timp de 1 an de zile, iar acum lucrează într-o şcoală gimnazială. În propria-i poveste, tot ce şi-a dorit, încă din copilărie, a fost să devină profesoară; jocul ei preferat era: „Nu-mi amintesc decât că eram mică şi aşezam jucăriile pe fotoliu şi le explicam şi lipeam afişe pe dulap şi explicam ce era acolo...doar atât îmi amintesc...".

Despre şcoală, Diana povesteşte ca despre o perioadă specială în via a ei, atunci se sim ea ea însăşi şi pentru mult timp, până când a devenit mamă, apropierea de şcoală (cunoaştere, lectură) pare să o fi reprezentat cel mai bine. Despre prezent, Diana vorbeşte cu multă dezamăgire; în povestea ei apar „schimbările”, mai exact, un context în care şcoala şi profesorii sunt privi i diferit fa ă de imaginea cu care ea se identifică. În diferite momente ale interviului, Diana exprimă resemnare, revoltă sau nemul umire de sine în raport cu situa ia în care se află.

A fost bursieră în Danemarca, şi perioada respectivă are o semnifica ie specială pentru Diana. Acolo, ea s-a sim it „,confortabilă” deoarece elevii şi părin ii valorizau şcoala şi profesorii: „Oamenii erau conştien i de ce sunt în şcoală”.

Acum, în şcoală, Diana se simte „străină”. Cu activitatea de predare, prezentul şi România, Diana asociază lipsa respectului pentru profesor, un servilism al profesorilor fa ă de părin i şi dezinteresul fa ă de lectură. În povestea Dianei, coexistă mai multe semnifica ii asociate profesorului. Când povesteşte despre sine, încă din copilărie, Diana se identifică cu imaginea unui maestru alături de discipolii săi, a fi profesor înseamnă a împărtăşi cât mai mult cunoştin e unor elevi „,conştien i” de importan a educa iei. $\mathrm{Cu}$ această imagine, Diana îi asociază pe profesorii săi, de la universitate: , , iş̧i ineau cursul şi cam atât, nu prea interac ionau foarte mult cu noi, ştii cum e la facultate, acolo e volumul mare de cunoştin e, n-are nimeni timp sa te gâdile pe tine să vadă dacă ai în eles sau nu, ai în eles bine, nu la revedere, simplu”. Despre ei, Diana vorbeşte cu respect, dar după un moment scurt de reflec ie, pare să-şi dea seama că a învă at să fie profesor, mai degrabă de la profesorii din Danemarca şi din practică. Când povesteşte despre ce a învă at şi cum lucrează cu elevii, a fi profesor înseamnă „s $\breve{a} n u$ vorbeşti singur”, ci ,să construieşti” cu elevii tăi, să le permi i să greşească, 
să îi sprijini, să îi încurajezi să se exprime în limba engleză. Când vorbeşte despre ceea ce se simte constrânsă să facă, Diana aduce în discu ie „preten iile părin ilor” şi faptul că rolul profesorului e redus la a nota în favoarea elevului: „Se aşteaptă de la noi probabil, cei care vin din familii unde mai vor ceva educa ie, se assteaptă să faci carte multă, să-i înve $i$, să le dai de lucru şi cei care au probleme, să îi laşi în pace, eventual să le dai 10 pe nimic, eu oricum dau 9 şi 10, eu oricum nu dau note mai mici”.

În concluziile interviului, profesoara Diana se descrie ca adaptându-se, împotriva aspira iilor ei, la nivelul scăzut al elevilor: „Da, păi, niciodată $n u$ o să mai predau, probabil, la nivelul, la care aş vrea să predau. Nu am cui, nu am cui şi, în mod automat, scad nivelul... în momentul în care nu se în elege, de fapt, ce să în eleagă dacă ei nu ştiu ce înseamnă prezent în româneşte".

\subsection{Discu ie}

Mihai şi Diana descriu practici asemănătoare la clasă; într-o oră obişnuită, fiecare explică şi/sau descoperă reguli împreună cu elevii, apoi ghidează elevii în aplicarea regulilor proaspăt învă ate. Însă, în răspunsurile sale, Mihai se prezintă preocupat să explice şi să se facă în eles, iar Diana se prezintă preocupată să împărtăşească cunoştin e elevilor, obligatoriu, cele prevăzute de programă. Pe Mihai îl supără profesorii care nu se asigură că elevul a în eles cele explicate, înainte de a-l evalua; pe Diana o supără elevii care nu se dovedesc interesa i (nu ascultă) de ceea ce ea poate să împărtăşească. Pe tema evaluării elevilor, Mihai se prezintă ca un profesor care dă note mai mari pentru că a învă at să ofere elevului ocazii repetate să-şi demonstreze cunoştin ele, dar care e „obiectiv în evaluare” şi nu este intimidat de presiunea părin ilor pe această temă. În povestea Dianei apare o contradic ie, ea se prezintă ca un profesor care dă numai note de 9 şi 10, dar care se simte opresată de această practică acceptată în şcoală. Diana este revoltată de „preten iile părin ilor” privind evaluarea elevilor.

Mihai se prezintă, mai degrabă, ca profesorul care trebuie să înlesnească în elegerea elevilor şi să noteze „,obiectiv”, iar Diana se prezintă mai degrabă 
ca profesorul care trebuie să transmită cunoştin ele prevăzute de programă şi să noteze ,flexibil”. Poveştile lor identitare dezvăluie idei posibile, aşezate în opozi ie, despre rolul profesorului: profesorul care transmite cunoştin e versus profesorul care înlesneşte în elegerea; profesorul „obiectiv” versus profesorul ,flexibil”.

\section{Programa în poveştile identitare ale profesorilor}

Una dintre temele aduse de majoritatea profesorilor intervieva i în discu ie, fără a fi întreba i de cercetător, a fost programa. În principal, profesorii au vorbit despre o incompatibilitate între programă şi metodele moderne. Însă, modul în care profesorii intervieva i justifică dacă şi cum folosesc programa, oferă noi indicii despre opozi iile cu care aceştia operează. Trebuie men ionat că sensul dat de profesori programei diferă de defini ia pedagogică. Aceştia povestesc despre programă ca despre un document care indică temele pe care trebuie să le „predea” elevilor şi ordinea în care trebuie să facă asta.

Mihai (profesor de fizică) şi Ioana (profesoară de engleză) se prezintă ca profesori care nu au nevoie de programă, din experien a anterioară, ei cunosc nivelul general la care trebuie să ajungă elevii şi îşi organizează activitatea didactică astfel încât să ajungă acolo, centrându-se pe nevoile elevilor. „,Nu folosesc programa...cred că am zis bine, da, programa, deci ştiu ce am de predat, ştiu capitolele pe care trebuie să le predau, merg după cum merge clasa şi încerc, în acelaşi timp, să termin tot ceea ce am de predat într-un an şcolar. Aşa sunt eu, cred că aşa ar trebui mers” (Mihai).

„Nu respect programa, respect nevoile celor din clasă [...] poate eu sunt pu in inconştientă, nu mi-a păsat niciodată de treburile astea, eu am făcut ceea ce am crezut eu că-i bine. Ii vorba despre o limbă străină, nu-i vorba de matematică, practic obiectivul final este să poată să vorbească şi să scrie, cum ajungi la chestia asta, cu programa aia sau fără programa aia..." (Ioana).

Maria (profesor de psihologie) foloseşte programa ca recomandare, se lasă ghidată, dar nu se simte obligată să se abată de la ritmul impus de progresul în elegerii elevilor: „pentru mine cel mai important este ca ei să în eleagă 
ceea ce am făcut. Mi s-a întâmplat să nu termin programa, de exemplu, acum nu am terminat programa, dar cred că cel pu in o parte au în eles-o. Nu mă interesează să trec la o lec ie următoare dacă ei nu au în eles-o pe cea anterioară...” (Maria).

Pe Diana, programa „o obligă”, aşa cum şi pe profesorii ei de la universitate, volumul mare de cunoştin e îi împiedica să se preocupe de evolu ia în elegerii studen ilor (,n-are nimeni timp sa te gâdile pe tine să vadă dacă ai în eles sau nu”). Diana e preocupată de în elegerea elevilor, justifică faptul că nu ea îi obligă pe elevi să înve e gramatică, ci programa aduce pe toată lumea în această situa ie. Ilinca (profesoară de limba şi literatura română) povesteşte, şi ea, despre stresul de „a preda” întreg con inutul programei. „Aaa, nu neapărat, [gramatica] o predau pentru că trebuie să o predau, dar nu mă deranjează dacă ei greşesc, dacă nu in minte nu ştiu ce regulă, nu-i for ez, nu-i oblig, nu, dar bineîn eles, trebuie predate şi astea, programa mă obligă [...]. Nu pot preda Present Perfect sau orice alt subiect de gramatică şi să se în eleagă decât în stilul clasic, adică le dai regula, facem exerci ii, ori, ei nu în eleg nici chestia asta” (Diana).

Modul în care responden ii se prezintă în rela ie cu programa îi împarte în două tabere, o parte dintre ei o aduc în discu ie pentru a sublinia că cel mai important este să te adaptezi la nevoile elevilor, indiferent de programă, al ii o folosesc pentru a-şi justifica preocuparea pentru transmiterea cunoştin elor şi compromisul necesar în raport cu nevoile elevilor. Povestind despre programă, profesorii formulează şi reîntăresc idei despre rolul profesorului: ca profesor, fie prioritizezi transmiterea cunoştin elor (programa), fie înlesnirea în elegerii. Aceste distinc ii cu care operează profesorii indică discursurile competitive din câmp.

\section{Evaluarea elevilor în poveştile identitare ale profesorilor}

Primii profesori intervieva i au adus în discu ie, fără a fi întreba i, notarea elevilor. Observând că tema reapare şi profesorii se pozi ionează ferm, am decis investigarea ei în fiecare din interviurile următoare şi introducerea unor cazuri contrastante. Ilinca (profesoară de limba şi literatura română), 
Anca (profesoară de limba şi literatura română) şi Sorana (profesoară de socio-umane) nu vorbesc despre sine în rela ie cu notarea elevilor, dar vorbesc despre un mers acceptat al lucrurilor, de a se da note mari: „Da, se dau note foarte mari, acuma, încă încercăm să echilibrăm pentru că nu mai este presiunea examenelor la facultate cu media anilor de liceu sau cu media la bac" (Anca).

Fără a fi întrebată direct, Ioana (profesoară de engleză) aduce în discu ie notarea elevilor pentru a se prezenta ca profesorul neadaptat din cancelarie, care nu a cedat presiunii să dea note mari. De asemenea, Ioana pare să observe un paradox, colegii săi au îmbră işat această schimbare împotriva voin ei lor: „Fraierii cancelariei sunt ăia care îşi fac treaba, se duc la ore, pun note pe bune. [...] Adică suntem câ iva, care încă mai inem la nişte chestii, dar şi ăia ne cam pierdem. Adică sunt încă pu ini care mai pun note pe bune. Astea sunt apreciate, dar nu sunt apreciate, cum să spun, şi de către profesori, şi de către elevi. Adică încă îşi dau seama, incă sunt unii care au coloană vertebrală, ştii, încă pot să facă ce se făcea odată şi ce făceau unii care chiar făceau şcoală, dar aprecierea asta e tacită cumva, adică nimeni nu te apreciază pe fa $\breve{a}$ pentru chestii de genul ăsta, dar cumva, te invidiază pentru că ei nu sunt în stare să facă chestiile astea” (Ioana).

Asemeni Dianei, Corina (profesoară de istorie) nu se identifică cu acest nou rol, dar se prezintă ca profesorul care s-a adaptat noilor condi ii, de teamă că îşi poate pierde locul de muncă: „nu mai sunt martir, ştafetă, de când s-a născut T., m-am conformat, ce spune şefu', fac! Vine dirigintele şi î i arată: $<$ uite numai note de 10, cum să ia 7 la disciplina X?, am şi eu nevoie de şef de promo ie!>. Trebuie să dau note bune? Le dau! Vreau să dorm liniştită. In 2001 eram strictă. E o competi ie, vin suplinitorii, se conformează, dau note bune, rela ionează mai bine, elevii cer să li se schimbe profesorul, $\hat{\imath} i$ pierzi pâinea” (Corina).

Ilinca nu se pozi ionează pe această temă, dar povesteşte cum s-a produs schimbarea: decizia universită ilor de a admite noi studen i în func ie şi media generală de absolvire a liceului, i-a adus pe părin i în situa ia de a căuta solu ii să crească şansele copiilor lor la studii superioare (fără taxă). 
„[Şi mai sunt alte schimbări pe care le-a i resim it?] Evaluarea elevilor. Notele au urcat, pentru că părin ii au pus presiune pe profesori. Mediile de liceu conduc la admiterea la facultate, ceea ce înainte de 2000, nu era. Atunci s-a ajuns la lucruri destul de grave. Părin ii au dorit, la clase, profesori care pun note mari, au evitat să aibă în încadrare profesori severi şi stric $i$ la note, pentru că le trebuia media, din liceu sau de la bac. [...] Şi atunci părin ii, au decis să nu $\hat{\imath} l$ dea la profesorii ce pun note doar sub 7, şi au optat pentru profesori ce pun note de la 7 în sus” (Ilinca).

Sorana, de asemenea, nu se pozi ionează explicit pe această temă, dar descrie limpede scenariul la care trebuie să se aştepte un profesor care nu se conformează noilor norme. În acest scenariu, unui profesor care nu răspunde aşteptărilor de notare ale elevilor şi părin ilor, i se poate cere să nu mai predea la clasa respectivă şi se poate ajunge la demiterea lui: „,[Dacă un profesor se răzvrăteşte, nu notează cu 2 puncte în plus, ce se întâmplă cu el?] Se poate răzvrăti, se întâmplă următorul lucru, tot aşa discret, se lucrează şi aparent nevinovat, clasa respectivă, din diferite motive, nu-l mai doreşte. Şi în momentul în care nu te doresc 3 sau 4 sau 5 clase, întrebi şi te întrebi la 50 de ani unde...ce faci? Părin ii fac scris la director, directorii nu vor nici unul scandal în institu ia lor, nimeni nu vrea, la modul general. Niciun director nu vrea să aibă probleme. Şi-atunci, zice: <Dom'le, da, las-o şi dumneata, las-o şi dumneata, s-au mai schimbat timpurile, s-au mai făcut, s-au mai dres, dacă te prinde undeva, află un context, ai şi tu un copil>” (Sorana).

Indiferent dacă se identifică sau nu cu profesorul care dă note mari, responden ii vorbesc despre nevoia de a fi ,flexibil" în notare, un fenomen apărut în ultimii ani. A fi ,flexibil” în notarea elevilor se opera ionalizează diferit pentru responden i: pentru Diana înseamnă să noteze elevii numai cu 9 şi 10, pentru Sorana şi Anca să dea note mai mari cu 2 puncte, pentru Corina să se adapteze la cerin ele dirigintelui sau elevilor. Referin ele profesorilor la evaluarea elevilor dezvăluie două noi reprezentări: profesorul „obiectiv” versus profesorul „flexibil”. 


\section{Discursuri competitive în câmpul studiat}

Poveştile identitare reconstituite ale lui Mihai şi ale Dianei, referin ele profesorilor la programă şi evaluarea elevilor dezvăluie idei posibile despre rolul profesorilor: profesorul care trebuie să transmită cunoştin e versus profesorul care trebuie să înlesnească în elegerea; profesorul care trebuie să noteze „obiectiv” versus profesorul care trebuie să noteze ,flexibil”. Privite din perspectiva foucaultiană, aceste idei posibile şi aşezate în opozi ie, oglindesc discursurile competitive din câmp (liceul studiat). În continuare, discursurile competitive sunt descrise folosind selec ii din limbajul responden ilor şi problematizate în termeni de dominan ă.

Profesorul transmite cunoştin e: Un profesor, în primul rând, trebuie „, să impărtăşească” cunoştin e. Profesorul trebuie să termine programa, să , $\hat{\imath} i$ inve $e$ ” pe elevi, să le dea „mult” de lucru. „Materia” trebuie predată, elevii trebuie să se „pregătească”; celor care „nu înva ă”, profesorul poate să le dea ceva „mai uşor” de lucru, dar cu aten ie, astfel încât să nu-i „tragă pe ceilal i în jos” şi ,s s̆ nu rămână în urmă cu materia”. Profesorul care nu respectă aceste norme nescrise, ,stă degeaba”, ,se joacă”, , sacrifică elevii buni” şi este o influen ă negativă pentru elevi.

Profesorul înlesneşte în elegerea: Un profesor, în primul rând, trebuie „să se coboare” la nivelul elevilor. Profesorul trebuie să capteze „aten ia” elevului, ,să explice” atent păr ile „,dificile” ale unei lec ii, să se abată de la programă dacă elevilor le lipsesc cunoştin e ,de baz $\breve{a}$ ” şi să progreseze cu materia în , ritmul” elevilor. Cu elevii care ,nu înva $\breve{a}$ ”, profesorul trebuie să încerce diferite ,,solu ii” de predare şi evaluare, dacă nu func ionează, „să anun e” părintele şi/sau dirigintele. Profesorii care nu respectă aceste norme nescrise, sunt „rigizi”, in „monolog”, ,vorbesc singuri... ei pun întrebarea, ei dau răspunsul” şi îi „pierd” pe elevi.

Cu excep ia lui Mihai, profesorii care sunt preocupa i mai degrabă să explice pe în elesul elevilor, auto-evaluează ceea ce fac ca abatere de la ceea ce „trebuie”. Dana, spre exemplu povesteşte: „Mai este o parte enormă şi vitală, interac iunea cu copilul în sine, în sensul că dacă te duci la o clasă şi vezi că elevii ăia au probleme în a citi un text şi silabisesc pe carte, cam orice strategie didactică, fantastică de a preda nu ştiu ce, 
sănătate, a fost; hai să citim, hai să scriem frumos, hai să povestim. Altfel, vorbeşti singur şi după aia te superi că de ce nu răspunde pruncul! Păi nu răspunde pentru că vorbeşti SF-uri. Culmea este că cei care ar trebui să te sus ină în demersul ăsta vin şi te întreabă, de ce nu există corela ie între programă şi activitatea dumneavoastră didactică?" (Dana, profesoară de istorie). Această non-conformitate pe care o resimte Dana, faptul că îşi descrie alegerile şi comportamentul ca o abatere de la ceea ce este corect institu ional, dezvăluie că în liceul studiat, un discurs dominant este că un profesor, în primul rând, trebuie să transmită cunoştin ele prevăzute în programă.

Profesorul „obiectiv”: Un profesor trebuie să noteze „obiectiv”. Acest lucru înseamnă că trebuie să aprecieze elevii folosind orice note de la 2 la 10, diferen ele dintre note trebuie să reflecte diferen ele dintre cunoştin ele elevilor. Un profesor care notează ,obiectiv” nu face excep ii când un elev foarte bun nu se pregăteşte sau un elev slab îi depăşeşte aşteptările. Profesorii care nu respectă aceste norme nescrise sunt „, de gască ”, „conformişti”, „fără coloană vertebrală” pentru că „pun note mai pe degeaba”. Cuvântul „obiectiv” este folosit cu ghilimele pentru că în interviuri, cuvântul este folosit cu un sens foarte specific, cel descris mai sus. Profesorii nu au făcut referin e cu privire la metodele şi condi iile propriu-zise de evaluare a elevilor care, în pedagogie, sunt asociate cu obiectivitatea în evaluare.

Profesorul „flexibil”: Un profesor trebuie să noteze „flexibil”. Acest lucru înseamnă că deciziile de notare ale elevilor trebuie să satisfacă cerin ele elevilor, părin ilor, dirigin ilor şi directorului, după cum urmează: în general, notele nu pot fi mici pentru că influen ează nota de intrare la universitate a elevilor; dacă profesorul predă o disciplină care nu este de examen, trebuie să dea note mari (peste 8 sau 9); dacă profesorul predă o disciplină socioumană la profilul real, aşteptările sale trebuie să fie mai scăzute; dacă elevul este şef de promo ie, are note foarte mari, sau, în alte situa ii privilegiate, profesorul trebuie să treacă cu vederea momentele în care este ,nepregătit”. Profesorii care nu respectă aceste norme nescrise, sunt „, stric $i$ ”, , strânşi la note”, „fraierii liceului”, ,martiri”, lipsi i de colegialitate pentru că „nu lasă loc de negociere”.

„Flexibilitatea” în notarea elevilor apare constant ca referin ă în auto- 
evaluările profesorilor. O parte dintre profesorii intervieva i nu se pozi ionează pe această temă, dar vorbesc despre notarea ,flexibilă” ca despre o stare de fapt a lucrurilor, al ii (Diana, Corina) resping acest mod de a defini rolul profesorului, chiar îşi exprimă revolta, dar se auto-evaluează şi oferă dovezi despre cât de ,flexibili” au devenit. Mihai (profesor de fizică) şi Ioana (profesoară de engleză) se prezintă ca „obiectivi”, dar Ioana, povestind despre modul în care ea şi Mihai notează elevii, foloseşte apelativul ,fraierii liceului”. Astfel, modul în care profesorii povestesc şi se auto-evaluează în raport cu ,flexibilitatea” în notare, dezvăluie faptul că un alt discurs dominant în liceul studiat este că profesorul trebuie să fie ,flexibil” în notare.

\section{Concluzii}

Analiza ne arată că poveştile identitare ale profesorilor sunt unice, la fel şi modul în care povestesc despre ei în rela ie cu evaluarea elevilor sau folosirea programei. În acelaşi timp, aceste poveşti dezvăluie următoarele discursuri posibile despre rolul profesorului: profesorul care transmite cunoştin e versus profesorul care înlesneşte în elegerea; profesorul „obiectiv” versus profesorul „flexibil”. Pe de altă parte, în poveştile lor identitare, profesorii formulează aprecieri la adresa lor sau a colegilor. Ideile în raport cu care profesorii se auto-evaluează şi se plasează în pozi ii centrale sau marginale, sunt interpretate ca discursuri dominante despre rolul profesorului. Analiza auto-evaluărilor profesorilor dezvăluie că, în liceul şi în perioada studiată (mai-iunie 2016), conform discursului dominant, profesorul trebuie să transmită cunoştin e şi să noteze „flexibil” elevii. Această concluzie nu trebuie interpretată în termeni de opinie a majorită ii, discursul dominant nu reflectă opinia majorită ii, ci reprezintă acele idei despre rolul profesorului, favorizate de politicile şi practici institu ionale şi care oglindesc rela ii de putere din liceu, la momentul cercetării.

Din perspectiva rela iilor de putere, profesorii se află într-o pozi ie paradoxală. Discursul centrării pe transmiterea cunoştin elor îi conferă profesorului o pozi ie privilegiată: el este cel care decide ce, când şi cum predă, iar elevul trebuie să se adapteze, dacă îşi doreşte recunoaştere. Discursul flexibilită ii în notare vulnerabilizează profesorul, de data aceasta, părin ii, directorul şi al i colegi pot cere mici „favoruri”, iar profesorul trebuie să se adapteze, 
dacă îşi doreşte recunoaştere sau să nu-şi piardă locul de muncă.

Conform profesorilor intervieva i, discursul flexibilită ii în notarea elevilor este favorizat în liceu, de un ansamblu de practici şi politici. Liceul oferă părin ilor posibilitatea să aleagă profesorii elevilor lor. Formal, conform acestei politici, dacă to i părin ii şi elevii unei clase semnează o peti ie de schimbare a profesorului, acesta este schimbat. Informal, au existat cazuri când conducerea liceului a oferit posibilitatea dirigin ilor sau părin ilor influen i din liceu (de exemplu, sponsori) să aleagă profesorii elevilor lor. O altă politică ce favorizează indirect flexibilitatea în notarea elevilor, apar ine universită ilor. Cei mai mul i profesori atribuie schimbările în notarea elevilor deciziei universită ilor de a include media generală de absolvire a liceului în criteriile de admitere la programele de licen ă.

Aceste politici şi practici nu influen ează, în mod direct, notarea elevilor, însă creează motiva ie şi ferestre de oportunitate pentru diverşi actori (părin i, dirigin i) să constrângă deciziile profesorilor. Astfel, profesorii se află în situa ia de a se adapta şi a evalua elevii ,flexibil" sau nu, ceea ce le conferă o pozi ie de nonconformitate (aşa cum povesteşte Ioana, vezi mai sus) şi îi supune riscului să li se ceară să nu mai predea la anumite clase, situa ie care e percepută ca un prim pas în drumul spre a-şi pierde locul de muncă (aşa cum descrie Sorana, mai sus, şi men ionează al i 3 responden i). Astfel, un profesor nu este constrâns direct să noteze ,flexibil”, ci de situa ia în care se regăseşte (imaginează).

În altă ordine de idei, datele colectate nu au permis identificarea practicilor şi politicilor institu ionale care privilegiază ideea că profesorul trebuie să transmită cunoştin e. În concluzie, în liceul studiat se poate vedea cum politica liceului de a permite elevilor şi părin ilor să-şi schimbe profesorii, numai pe bază de consens, în contextul politicilor universită ilor de a include media generală de absolvire a liceului în criteriile de admitere la programele de licen ă, favorizează discursul că profesorul trebuie să noteze flexibil. Întorcându-ne la întrebarea de cercetare, investiga ia arată că, în liceul studiat, există următoarele discursuri competitive despre rolul profesorului: profesorul trebuie să transmită cunoştin e versus profesorul trebuie să înlesnească în elegerea; profesorul trebuie să noteze „obiectiv” versus profesorul trebuie să noteze ,flexibil". 
Concluziile acestei cercetări nu trebuie generalizate în contexte diferite semnificativ de liceul studiat. Spre exemplu, într-o şcoală profesională, cu elevi care nu inten ionează să urmeze studii superioare, flexibilitatea în notare s-ar putea să nu fie definitorie pentru aşteptările de la profesori.

\section{Note}

Autoarea foloseşte interschimbabil termenii poveste şi nara iune.

2 Participan ii la studiu sunt prezenta i sub pseudonime.

\section{Referin e}

- Alsup, J. (2008). A Teaching Life: How and Why This Project Came to Be. Teacher Identity Discourses. Taylor \& Francis e-Library.

- Ball, S.J. (2013). Foucault Power and Education. New York: Routledge.

- Beauchamp, C., \& Thomas, L. (2009). Understanding teacher identity: an overview of issues in the literature and implications for teacher education. Cambridge Journal of Education, 39(2), 175-189. https://doi.org/10.1080/ 03057640902902252.

- Best, J.W., \& Kahn, J.V. (2006). Research in education. Boston: Pearson.

- Cohen, J. L. (2008). 'That's not treating you as a professional': teachers constructing complex professional identities through talk. Teachers and Teaching: theory and practice, 14(2), 79-93. https://doi.org/10.1080/135406 00801965861.

- Comşa, M. (n.d.). Designul şi practica cercetării sociale. Manuscris nepublicat.

- Creswell (2007). Ch 07 Data Collection Introducing and Focusing the Study. Qualitative Inquiry and Research Design. Londra: Sage, 117-145.

- Dawson, C. (2002). Practical Research Methods - a user-friendly guide to mastering research. United Kingdom: How to books.

- Foucault, M. (1998). Ordinea discursului. Bucureşti: Eurosong\&Book.

- Gibbs, G.R. (2015). Discourse analysis Part 2 Foucauldian and critical approaches [prezentare video]: https://www.youtube.com/watch?v=E_ffCsQx2Cg.

- Sfard, A., \& Prusak, A. (2015). Telling Identities: In Search of an Analytic Tool for Investigating Learning as a Culturally Shaped Activity. Educational Researcher, 34(4), 14-22. https://doi.org/10.3102/0013189X034004014.

- Spratt, J. (2017). Wellbeing, equity and education. Inclusive Learning. Springer. https://doi.org/10.1007/978-3-319-50066-9. 
- Stănciulescu, E. (2005). Metode calitative. Suport de curs nepublicat accesat la http://elisabetastanciulescu.ro/wp-content/uploads/2011/03/Observatiacantitativa-si-calitativa_Esantionarea-calitativa_.pdf.

The online version of this article can be found at: http://revped.ise.ro/category/2018-en/

\section{(cc) $\mathrm{BY}-\mathrm{Ne}-\mathrm{BA}$}

This work is licensed under the Creative Commons Attribution-NonCommercial-ShareAlike 4.0 International License.

To view a copy of this license, visithttp://creativecommons.org/licenses/by-ncsa/4.0/ or send a letter to Creative Commons, $P O$ Box 1866, Mountain View, CA 94042, USA.
Versiunea online a acestui articol poate fi găsită la:http://revped.ise.ro/category/2018-ro/

\section{$( c c ) \longdiv { B Y - N C - S A }$}

Această lucrare este licen iată sub Creative Commons Attribution-NonCommercial-ShareAlike 4.0 International License.

Pentru a vedea o copie a acestei licen e, vizita $i$ http://creativecommons.org/licenses/by-nc-sa/4.0/ sau trimite i o scrisoare către Creative Commons, PO Box 1866, Mountain View, CA 94042, SUA. 